ENTREPRENEURSHIP AND SUSTAINABILITY ISSUES

ISSN 2345-0282 (online) http://jssidoi.org/jesi/

2021 Volume 9 Number 2 (December)

http://doi.org/10.9770/jesi.2021.9.2(15)

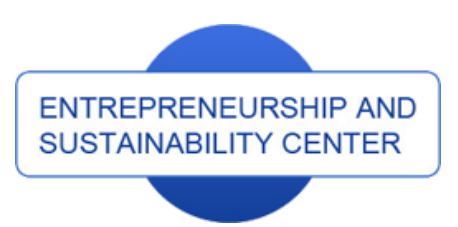

Publisher

http://jssidoi.org/esc/home
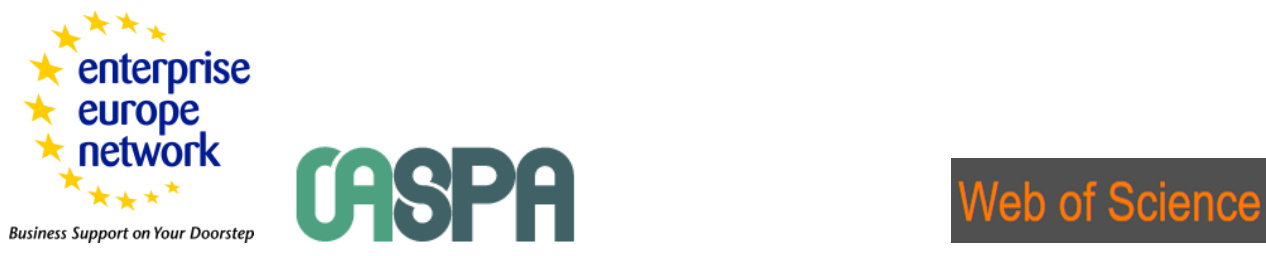

1) Clarivate

Analytics

\title{
CRISIS DIAGNOSIS IN CROSS-BORDER REGIONS: LESSONS FROM THE PANDEMIC
}

\author{
Michał Bilczak \\ University of Warmia and Mazury in Olsztyn, Faculty of Economic Sciences, ul. Oczapowskiego 2, 10-719, Olsztyn \\ Poland \\ E-mail: $\underline{\text { michal.bilczak@uwm.edu.pl }}$
}

Received 18 August 2021; accepted 10 October 2021; published 30 December 2021

\begin{abstract}
In the article, methods and tools for diagnosing crisis phenomena in the conditions of the COVID-19 pandemic, based on the example of border regions of the Baltic Sea countries and the Northwestern Federal District of the Russian Federation, were presented. Governmental measures and restrictions on the functioning of the economic subjects introduced in the border regions caused some shock and stress situation, which are of great importance for the course of the crisis conditions and the way out of the crisis. The purpose of the diagnosis is to establish a specific recognition of the research object, to provide a specific description and to formulate a final document or a conclusion about the condition of this object within a specified research completion date. In other words, the diagnosis allows the determination of the state of the research object and the development of a conclusion from these results, which can be based on indicators, coefficients, standards, in order to propose real positive changes up to the definition of the strategy and development tactics. The study uses the methods of systemic, structural, factor and comparative analysis, considering common and available parameters. A qualitative diagnosis of the object is carried out based on the algorithm and research stages. Specific problems are investigated on the basis of indicators and characteristics that are comparable in studies of corona crisis phenomena. Currently, the frontier economy is facing new challenges that test the basic mechanisms of functioning in crisis conditions. All these processes imply measures to eliminate the consequences of post-pandemic phenomena. This research can be used by the public administration units in diagnosing the processes of cross-border cooperation in the period of recovering from the post-pandemic crisis.
\end{abstract}

Keywords: cross-border cooperation; cross-border region; border region; COVID-19 pandemic; diagnosis; diagnostic algorithm; crisis modeling

Reference to this paper should be made as follows: Bilczak, M. 2021. Crisis diagnosis in cross-border region: lessons from the pandemic. Entrepreneurship and Sustainability Issues, 9(2), 223-237. http://doi.org/10.9770/jesi.2021.9.2(15)

JEL Classifications: F02, F50 


\section{ENTREPRENEURSHIP AND SUSTAINABILITY ISSUES}

ISSN 2345-0282 (online) http://jssidoi.org/jesi/

2021 Volume 9 Number 2 (December)

http://doi.org/10.9770/jesi.2021.9.2(15)

\section{Introduction}

It should be noted that to date the situation is exacerbated by exceptional uncertainty about the measures taken by public administration bodies in the border regions. This is primarily the lack of diagnostics and measures for the introduction of quarantine in certain sectors, forced constraints on the economic and commercial activity of the population, restrictions on the access of the entire population to recreation and entertainment sectors, the transition to distance learning in schools and universities and the closure of children's and pre-school institutions. At present, the scale and nature of the impact of all these artificial restrictions in various industries and sectors of the economy is unclear. All this increases the complexity of diagnostics in the current crisis conditions. In the scientific literature the problems of diagnosis of corona crisis phenomena have not yet been studied, so the realization of the purpose and relevance of this study is of great importance. The research material is based on the example of the Baltic Sea countries and, to a greater extent, the border regions of the Northwestern Federal District (NWFD) of the Russian Federation. Russia is also a Baltic Sea country, but the scale and difference in the comparison of research would not be correct. Therefore, only one out of eight federal districts of Russia has been chosen, which borders with the countries of the European Union and has a direct relation to the Baltic Sea. It seems that this choice is correct and fully contributes to the realization of the research goal. In recent years, diagnostics as a research category has been boldly used in the assessment of cross-border cooperation. It plays the role of the most important scientific method and tool that enables answering many crisis problems in practically all researches.

The literature review section is built on a wide selection of COVID-19 related materials. The unfolding economic crisis has shown that many scholars are trying to make sense of the economic consequences of the corona crisis. For example, Ludvigson et al. (2020) found that the corona crisis is a major multi-period exogenous shock. Baker et al. (2020) note that COVID-19 led to a massive spike in uncertainty and no close studies exist in science. The authors found that a corona crisis shock results in an $11 \%$ annualized decrease in GDP. In another very important study (König \& Winkler 2020), which was conducted on a sample of 42 countries (mostly European), it has been studied how coronavirus mortality rates affect GDP growth. Researchers note that the stringency of enforcement measures is an important factor in growth. For example, stricter measures lead to lower GDP in the quarter studied, but are associated with a positive catch-up growth effect in the next quarter. The impact of the corona crisis has enormous implications for the labor market. For example, Adams-Prassl et al. (2020), Beland et al. (2020) found that forced business closures lead to sharp unemployment and will have severe economic consequences in the long run.

In addition, many sources (Will 2020; Knight 2017; Zizka 2020) express dismay and bewilderment as to why political elites have been largely unprepared for this crisis. Scholars write of the deliberate ignorance and low qualifications of decision makers. Late response, complete confusion in the supply of medical drugs and the provision of ICU beds led to unfortunate consequences. Van Dam and Webbink (2020, p. 13) note that "everyone can define the problem and its cause inone's own way to derive one's favourite solution to the problem. Whatever measureis implemented to counter the crisis can be labelled anything from overreacting andcreating panic to ignoring the seriousness and wilful negligence". In the section related to research methodology and to some aspects of corona crisis diagnostics in the Baltic Sea countries, examples of qualitative diagnostics of corona crisis phenomena and corresponding forms, methods and means, which allow to receive certain guarantees against probable errors and calculations in concrete anti-crisis situations, are shown. On the basis of the algorithm and the corresponding toolkit, specific measures to support business entities and the population, which have been artificially limited in their activities, resulting in huge losses or job losses, are proposed. In the results section, specific examples of the corona crisis in the Baltic Sea countries and in the NWFD regions are discussed. The conclusions contain specific recommendations, as well as lessons learned from the pandemic that must considered in real and practical life and in the prevention of such diseases in the future. 


\section{ENTREPRENEURSHIP AND SUSTAINABILITY ISSUES}

ISSN 2345-0282 (online) http://jssidoi.org/jesi/

2021 Volume 9 Number 2 (December)

http://doi.org/10.9770/jesi.2021.9.2(15)

\section{Literature review}

The COVID-19 pandemic has caused an unprecedented economic crisis and has had extremely negative effects on economic activity, GDP growth, and unemployment (König \& Winkler 2020). In addition, studies on the Baltic Sea countries confirm this conclusion (Ehle 2020). The author conducted an interesting study on German regions (401 counties were studied), which shows that there are inter-regional differences in the level of socioeconomic, demographic and health variables affecting the economy in a corona crisis. Using the example of another Baltic Sea country, Denmark (Marinov 2020), a number of important issues related to the specific socioeconomic characteristics of the country, which affected the Danish economy in a pandemic, are examined. Particular attention is paid to the measures taken by the government in the labor market, household consumption, and entrepreneurial activity. Hensvik et al. (2020) in their paper show the changes caused by COVID-19 in the Swedish labor market. The authors give the example of a $40 \%$ decrease in vacancies during the first three months after the COVID-19 outbreak. The resulting tightness in the labor market redistributed job searches towards less affected occupations regardless of changes in job vacancies.

The unfolding economic corona crisis has classic and new unique features. Declines in production and international trade, financial shocks and tensions in economic activities are classic features of any crisis. New problems are primarily related to the denial of movement of people at all levels and their isolation at different scales (country, city, community). Therefore, a significant part of production is practically paralyzed and the decline in economic activity dependent on measures of isolation reaches impressive proportions (up to 30-40\%). The duration of the isolation period is still unknown and there is no clear certainty about the mode of operation, removal of quarantine measures, contacts of the population and their movement. The pandemic struck practically the entire world economy and all countries were forced to implement quite severe restrictions, which in turn led to a sharp decline in production and exchange (Opiłowska 2020; Hauser et al. 2020; Van Dam \& Webbink 2020).

It can be seen as alarming that there is virtually no clear diagnosis on the problems of recovery from these crisis situations. As of today, it is only known that the pace of the economic recovery will depend on the severity and duration of quarantine measures, the restoration of border relations with neighboring regions, the restoration of trade relations, and the level of support for business by public administration bodies at all levels. Many governments have already announced plans to support economic actors at sectoral and industry levels, including support for small and medium-sized enterprises (Zemtsov et al. 2020; Knickel et al. 2021). It is expected that systemic understanding and assessment, and preferably diagnostics, will allow a rational approach to the threats and barriers posed by a pandemic. Quantitative risk assessment and tools have been based on the diagnosis of emerging crises for over 50 years.

However, there are also criteria that can help all businesses specifically. They concern, first of all, how business will behave under the current crisis conditions. Charles Darwin wrote: "It is not the strongest or the cleverest who survive, but the one who adapts best to change". It seems that in the conditions of the pandemic, it is not those who argue about lost opportunities who will survive, but those who understand that it is no longer possible to live the old way. New conditions have emerged, new requirements that demand every entrepreneur to be very active and make incredible efforts to develop in the new environment.

The study is built on an in-depth diagnosis of the causes that emerged during the expansion of the COVID-19 pandemic (Breznau 2021; Claeson \& Hanson 2021 Shet et al. 2020; Kucharski et al. 2020). For example, early findings on the development of the pandemic have already provided guidance on the scale and direction in which to focus crisis response and increase support for businesses and populations.

It should be emphasized that the diagnosis of crisis phenomena in cross-border systems has its basic parameters and forms. Any parameters represent a system of criteria that reveal the specifics of a particular object. If we 


\section{ENTREPRENEURSHIP AND SUSTAINABILITY ISSUES}

ISSN 2345-0282 (online) http://jssidoi.org/jesi/

2021 Volume 9 Number 2 (December)

http://doi.org/10.9770/jesi.2021.9.2(15)

consider pandemic crisis phenomena in border regions, then it will be a system of indicators of qualitative characteristics and indicators of crisis research, taking into account the relevant factors influencing it in a particular period of time. In order to qualitatively investigate the crisis phenomenon in border regions, a system of criteria and indicators is required, i.e. a system of indicators is selected to assess the state of crisis objects and the development on this basis of qualitative and quantitative indicators (scales) to measure the corresponding values. Since the border region is a peripheral territory of the state and, as a rule, is a depressed territory, the relevant indicators, coefficients and scales are developed by science qualitatively enough, and they will be presented (Zgonnik 2015).

However, it should be properly understood that the diagnosis of such processes should provide for the classification of emerging deviations, as well as the most important parameters of the studied pandemic crisis phenomena and their manifestations. In this case, the procedure of information collection and processing will be generally accepted. If we consider the specifics of development of border regions under pandemic conditions, it is desirable to highlight the comparison of the object under study and especially its state comparable to the norm or benchmark (with developed regions of the country) for diagnostic studies. This will make it possible to identify the presence of deviations and determine their nature regardless of whether it will be positive or negative (Balashov 2004; Korotkov 2020; Belyaev 2015; Larionov et al. 2019).

\section{Research methodology and some aspects of diagnosis of corona crisis in the Baltic Sea countries}

A qualitative diagnostic result is the first condition for the successful development and functioning of the economy of border regions in the post-pandemic time and the possibility to prevent a crisis situation in all spheres of the border economy. Of course, the minimization of negative consequences of crisis phenomena in postpandemic time is central to the activities of governing bodies. However, in the border conditions of the regions of the Baltic Sea countries and NWFD regions of the Russian Federation, it is shown in the empirical part of the study, there is its own specificity and features when unforeseen circumstances arise, and all kinds of business activities are associated with relevant changes. In minimizing these problems diagnostic studies help to develop appropriate forms, methods and means, which allow to obtain certain guarantees against probable errors and miscalculations in anti-crisis situations.

For example, the problems encountered during the pandemic in the coastal regions of the NWFD show considerable variation in the level of socio-economic shock and stress. Diagnostics in NWFD regions is closely connected with controlling, where problems are formulated, and analysis begins, the purpose of which is to identify the real discrepancies, reduction or increase of deformation, actual and optimal state of the most important corona crisis situations. Key parameters of the corona crisis situation are defined, then specific problems are highlighted, there may be five to ten or more of them. Then we determine the sequence of operations: problem analysis, identification of the primary problem, analysis of the primary problem, diagnosis of the primary problem, and a diagnosis is established. On the basis of this diagnosis, forecasting and decisionmaking to eliminate contradictions is developed. It is very important that this process proceeds on the basis of specific indicators. In a pandemic, there are unifying indicators and characteristics that are comparable in corona crisis situations and allow the following lessons to be identified:

The first lesson is the general level of development of the border region. At the time of the study, the region is experiencing a deep economic crisis. There is a low rate of production. It has been in a phase of restriction and quarantine for a long time, a radical restructuring and, in some cases, diversification of production is required.

The second lesson is to assess the condition of industries and sectors that have been forcibly closed or artificially restricted since the beginning of the pandemic. The losses incurred and the support needed, including the 


\section{ENTREPRENEURSHIP AND SUSTAINABILITY ISSUES}

ISSN 2345-0282 (online) http://jssidoi.org/jesi/

2021 Volume 9 Number 2 (December)

http://doi.org/10.9770/jesi.2021.9.2(15)

compensation of financial losses, are to be determined. In the Baltic Sea countries, the most affected sectors are tourism, hotels, gastronomy, airports, passenger seaports, etc.

The third lesson is the state of the social sphere. There is a decrease in income and living standards, unemployment, the levels of social services and the level of educational services are decreasing due to restrictive measures and the artificial closure of certain industries. The analysis shows that some countries of the Baltic Sea suffered from the corona crisis more than other European countries. First of all, there was a belated reaction to the growth of coronavirus infections (Poland), or complete neglect of restrictive measures at the beginning of the pandemic in Sweden.

The fourth lesson is investment activity. In a pandemic, the border region has no investment appeal, there is a high risk for entrepreneurial activity, and there is little development of new activities in post-pandemic times.

The fifth lesson is closely related to health care. Determination of the general level of health care facilities, provision with modern equipment, apparatus and medicines. Introduce mandatory coefficients of sufficient provision of the population with services of inpatient medical institutions. Allocate additional budgetary places for medical students, especially in specialties that are directly related to infectious diseases. Provide budget funding for the construction of new inpatient medical facilities for viral diseases.

The sixth lesson is the labor market and employment. Indicators of falling demand for labor, due to the temporary closure or bankruptcy of businesses. Measures to restore and create new jobs, training and retraining, support and preferences for enterprises that create new production and activities, and therefore new jobs. Cardinal measures to revitalize micro, small and medium-sized enterprises and create incentives to hire new workers.

The seventh lesson is personal income. Declining wages, low real income per capita. The high level of unemployment. Obligatory conditions for a way out of the crisis not to forget behind difficult and difficult decisions, to really support incomes of the population and curb inflation. We are talking first and foremost about the poorest segments of the population, who must already today be really helped to overcome the subsistence level and get a foothold in the new conditions. Substantial measures should be developed to support people who have lost their jobs during the pandemic and help them find work.

It should be considered that the diagnosis of the above-mentioned lessons and characteristics on both sides of the border may differ significantly, but by the trends and nature of deviations it is possible to establish forecasts for the joint elimination of crisis phenomena in the respective spheres.

Linear programming is particularly valuable in diagnosing corona crisis in the Baltic Sea countries and NWFD regions. It is a mathematical technique that allows us to find the best combination of resources and actions necessary to achieve the optimal result. The linear technique allows to optimize any process, to calculate the increase of new jobs, the growth of unemployment and the growth of profits, to calculate the efficiency of the use of potential, resources and time to overcome the corona crisis. In linear programming quantifies the goal, the parameters that will be subjected to this mathematical technique and the available benchmarks and constraints in the use of resources, capacities on a time-specific basis. Modeling of the assessment of the use of the potential of the regional-economic space in the Baltic Sea countries and NWFD regions is proposed in the post-crisis time in four stages.

At the first stage, a dynamic criterion is formed, in which the criterion order of indicators is selected. This order is a rank series, in which the indicators included in the list are ordered according to the criterion adopted. These are 


\section{ENTREPRENEURSHIP AND SUSTAINABILITY ISSUES}

ISSN 2345-0282 (online) http://jssidoi.org/jesi/ 2021 Volume 9 Number 2 (December)

http://doi.org/10.9770/jesi.2021.9.2(15)

indicators that characterize basic and auxiliary economic processes, and indicators that characterize the processes of life support in a crisis, as well as processes that impede the implementation of aggregate anti-crisis measures (Biyakov 2004). Since these indicators are heterogeneous in terms of units of measurement, there is a problem of comparing them. At the second stage, the comparison of indicators is solved by means of the procedure of smoothing the initial data. For primary processing of time series, the procedure of smoothing - median is offered. Let the time series $A_{1}, A_{2}, \ldots A_{K}$ be given, then each new element of the smoothed series $C i$ is calculated by the following formula:

$$
C_{i}=1+\left(A_{i}-M e\right) /\left(A_{\max }-A_{\min }+1\right), i=1 \ldots k,
$$

where $M e$ is the median of the time series, $A_{\max }$ is the maximal member of the series, $A_{\min }$ is the minimum member of the series.

It should be noted that when trying to approximate the original data and the median-smoothed data, we obtain almost the same type of functions. This means that when calculating, for example, the growth rates after the median transformation in each time series there are no zero and negative components with almost complete coincidence of this trend with the original one. Here we get a serious advantage, especially if the calculations use value indicators (financial results of economic activity).

At the third stage of model building the actual rank series of movement of indicators are formed. To do this, it is necessary to calculate the growth rate of the indicators, to calculate the acceleration and changes in the values of the indicators. Finally, the list of indicators is ranked according to the decreasing value of the acceleration of their movement. In other words, the first rank is assigned to the indicator with the greatest acceleration, and the last rank is assigned to the indicator with the least acceleration. Based on these calculations, the rank matrix of indicator movement is constructed (table 1).

Table 1. Ranking matrix of the movement of indicators

\begin{tabular}{|c|c|c|c|c|c|c|}
\hline \multirow{2}{*}{ Indicator name } & \multirow{2}{*}{$\begin{array}{c}\text { Criterion order of } \\
\text { movement }\end{array}$} & \multicolumn{5}{|c|}{ Actual order of movement by period } \\
\cline { 3 - 7 } & 1 & $\mathrm{~T} 1$ & $\mathrm{~T} 2$ & $\mathrm{~T} 3$ & $\ldots$ & $\mathrm{TK}$ \\
\hline Indicator 1 & 2 & $X_{11}$ & $X_{12}$ & $X_{13}$ & $\ldots$ & $X_{I K}$ \\
\hline Indicator 2 & $>3$ & $X_{21}$ & $X_{22}$ & $X_{23}$ & $\ldots$ & $X_{2 K}$ \\
\hline$>$ Indicator 3 & $\ldots$ & $X_{31}$ & $X_{32}$ & $X_{33}$ & $\ldots$ & $X_{3 K}$ \\
\hline$\ldots$ & $\mathrm{N}$ & $\ldots$ & $\ldots$ & $\ldots$ & $\ldots$ & $\ldots$ \\
\hline Indicator N & $X_{N 1}$ & $X_{N 2}$ & $X_{N 3}$ & $\ldots$ & $X_{N K}$ \\
\hline
\end{tabular}

At the fourth stage two rank series are compared: criterial and actual. These series, as a rule, differ from each other by the difference between the numbers of individual indicators and the inversion of one complete series in relation to the other. In this method it is necessary to assess the proximity of the actual and normative orders. For this purpose Spearman and Kendall rank correlation coefficients are used.

The Spearman rank correlation coefficient is calculated on the basis of two steps. The first step - for each indicator from the list the square of the difference (deviation) between its place (rank) in the normative ordering and the rank in the actual ordering is calculated according to the formula:

$$
Y_{i}=\left(X_{i}-X_{k}\right)^{2}
$$

where $Y_{i}$ - the difference between the rank of the $i$-th indicator in the criterial ordering and the actual one, $X_{k}-$ the rank of the indicator in the criterial ordering, $X_{i}$ - the rank of the indicator in the actual ordering. 
Second step. The sum of squares of deviations for all indicators in the time period under consideration is calculated and the Spearman coefficient is calculated according to the formula:

$$
K_{\text {deviat }}=1-\frac{6 \times \sum_{i=1}^{N} Y}{N \times\left(N^{2}-1\right)}
$$

Kendall's rank correlation coefficient is calculated at two levels. At the first level, for each indicator, the number of other indicators with a place in the criterial ordering greater than that of the indicator in question, and in the actual ordering, a rank smaller than that of the indicator in question, is calculated:

$$
S=\sum_{p=k+1}^{N} a_{p}, a_{p}=\left\{\begin{array}{l}
1, x_{k}>x_{i} \\
0, x_{k}>x_{i}
\end{array}\right.
$$

where $k$ - the place of the indicator under consideration in the criterial ordering, $S$ is the number of inversions for a given indicator, $p$ - the places of the indicators compared to the indicator under consideration, $N-$ the number of indicators included in the list of system characteristics, $a_{p}$ is a function showing whether or not the indicator in question is inversion with the indicator compared to it (if yes, then $a_{p}=1$, otherwise $a_{p}=0$ ), $x_{k}\left(x_{i}\right)$ is the rank of the indicator in the actual ordering that has $k(\mathrm{p})$ place in the criterial ordering.

At the second level, the total number of inversions for all indicators is calculated and the Kendall correlation coefficient is determined:

$$
K_{\text {invers }}=1-\frac{4 \times \sum_{i=1}^{N} s}{N \times(N-1)}
$$

Both coefficients ( $K_{\text {deviat }}, K_{\text {invers }}$ ) estimate the closeness of the given rank series to the reference (criterion) series on the interval from 1 to +1 . The score +1 is obtained when the actual series coincides with the criterion series, and 1 when they are completely differently directed.

The indicator of the resulting assessment of the proximity of the actual structure of the system indicators movement to the criterial (benchmark), based on the two rank correlation coefficients for a given time period, can be calculated by the formula:

$$
R=\frac{\left(1+K_{\text {deviat }}\right) \times\left(1+K_{\text {invers }}\right)}{4}
$$

The resulting evaluation shows to what extent the nature of changes in the structure of the links of the system corresponds to the chosen evaluation criterion. In other words, we can say that this indicator allows us to evaluate the effectiveness of the managerial decisions made in accordance with the criterion set. The range of variation of this index is from 0 to +1 . At that, 1 - full coincidence of changes in the structure of the system connections with the chosen criterion; 0 - full discrepancy of changes in the system concerning the chosen criterion.

In addition to the quantitative assessment of the use of the potential of the region's economic space, a qualitative assessment is also calculated. The qualitative assessment of the weighting coefficients is calculated on the basis of the use of an exponential dependence on the number inverse of the ordinal number. 


\section{ENTREPRENEURSHIP AND SUSTAINABILITY ISSUES}

ISSN 2345-0282 (online) http://jssidoi.org/jesi/ 2021 Volume 9 Number 2 (December)

http://doi.org/10.9770/jesi.2021.9.2(15)

$$
w_{i}=\frac{e^{(1 / i)}}{\sum_{j=1}^{n} e^{(1 / j)}}
$$

where $w_{i}$-weighting coefficient of the indicator occupying the $i$-th place in the block, $e$ is the base of the natural logarithm, $n$ is the number of indicators in the block.

Border territories, being at the same time peripheral due to their remoteness from the centers of growth and attraction, are mostly depressed or underdeveloped (Sohn 2014). Mitigation of interregional contrasts in the conditions of the crisis, pulling backward and depressed regions up to highly developed territories is the main task of state authorities.

\section{Results}

The pandemic showed that COVID-19 did what no other virus has managed to do in the last century. During the pandemic, not only the economy, but also the social life of the population was significantly affected: quarantine, isolation, other restrictions on human freedoms, the loss of loved ones and the complete uncertainty of what comes next. Thus, COVID-19 has become a complete scientific puzzle for world science, and the threat of infection is now more relevant than it used to be (Korolev 2020; Wu et al. 2020; Coccia 2020; Janssen \& van der Voort 2020). In the Baltic region, the pandemic has affected all countries, limiting the normal freedom of movement of goods, persons, services and capital. Particularly large costs have occurred in cross-border integration and internationalization processes (Klatt 2020; Jańczak 2020; Hennig 2021). In the conducted research it was shown that in the Baltic Sea countries, the course of the pandemic has revealed all the contradictions and possible costs that characterize this artificial crisis. This is evidenced by the GDP data (table 2).

Table 2. Gross domestic product of the EU Baltic Sea countries

\begin{tabular}{|l|c|c|c|c|c|c|}
\hline \multirow{2}{*}{ Baltic Sea countries } & \multicolumn{2}{c|}{ GDP (current prices, million euros) } & Real GDP growth rate, \% & \multicolumn{2}{c|}{ GDP per capita, euros } \\
\cline { 2 - 7 } & 2019 & 2020 & 2019 & 2020 & 2019 & 2020 \\
\hline Germany & $3,449,050$ & $3,332,230$ & 0.6 & -4.9 & 41,510 & 40,070 \\
\hline Poland & $532,329.2$ & $521,514.5$ & 4.5 & -2.7 & 13,870 & 13,600 \\
\hline Sweden & $474,550.5$ & $472,260.1$ & 1.4 & -2.8 & 46,170 & 45,610 \\
\hline Denmark & $312,747.2$ & 311,726 & 2.8 & -2.7 & 53,760 & 53,470 \\
\hline Lithuania & $48,797.4$ & $48,794.2$ & 4.3 & -0.8 & 17,460 & 17,460 \\
\hline Latvia & $30,420.9$ & 29,334 & 2.0 & -3.6 & 15,900 & 15,430 \\
\hline Estonia & $28,112.4$ & $27,166.9$ & 5.0 & -2.9 & 21,220 & 20,440 \\
\hline Finland & 240,261 & 237,467 & 1.3 & -2.8 & 43,510 & 42,940 \\
\hline
\end{tabular}

Source: compiled from Eurostat data

It should be noted that Lithuania, Sweden and Estonia (7,721.52; 7,369.57 and 7,346.66 respectively) have the highest number of cases per 100,000 people, although detected COVID-19 cases are highest in Germany and Poland (table 3). However, the most "severe" indicator, which characterizes the state and the course of the pandemic is the mortality rate per 100,000 people. That's why Poland and Sweden are ahead of other countries of the Baltic Sea (131.48 and 131.32 respectively). This indicator is exceptionally hard for the population and clearly shows that state administration bodies and other institutions of the states do not cope with the epidemic of coronavirus in full measure. It should be noted that in the Baltic Sea countries the pandemic scenarios were formed more optimally compared to other European states. The calmer situation was achieved by timely restrictive measures on public transport and crowded areas, quarantine measures and some more conscious public 


\section{ENTREPRENEURSHIP AND SUSTAINABILITY ISSUES}

ISSN 2345-0282 (online) http://jssidoi.org/jesi/ 2021 Volume 9 Number 2 (December) http://doi.org/10.9770/jesi.2021.9.2(15)

attitude towards the pandemic. Nevertheless, even in those countries, in which the incidence rates are lowest, population is experiencing the full impact of the crisis.

Table 3. Main characteristics of the epidemic spread in the EU Baltic Sea countries as of March 24, 2021

\begin{tabular}{|l|c|c|c|c|c|}
\hline Baltic Sea countries & $\begin{array}{c}\text { Population } \\
\text { at the beginning of } 2021\end{array}$ & $\begin{array}{c}\text { The total number } \\
\text { of detected }\end{array}$ & $\begin{array}{c}\text { Number of cases per } \\
100,000 \text { people. }\end{array}$ & Mortality & $\begin{array}{c}\text { Mortality per } \\
100,000 \text { people. }\end{array}$ \\
\hline Germany & $83,166,711$ & $2,647,710$ & $3,192.39$ & 74,964 & 89.47 \\
\hline Poland & $37,958,138$ & $2,089,869$ & $5,521.94$ & 49,761 & 131.48 \\
\hline Sweden & $10,327,589$ & 744,272 & $7,369.57$ & 13,262 & 131.32 \\
\hline Denmark & $5,822,763$ & 226,277 & $3,906.58$ & 2,402 & 41.47 \\
\hline Lithuania & $2,794,090$ & 210,202 & $7,721.52$ & 3,501 & 128.61 \\
\hline Latvia & $1,907,675$ & 97,586 & $5,173.69$ & 1,828 & 96.91 \\
\hline Estonia & $1,328,976$ & 97,456 & $7,346.66$ & 809 & 60.99 \\
\hline Finland & $5,525,292$ & 72,073 & $1,300.79$ & 808 & 14.58 \\
\hline
\end{tabular}

Source: compiled from World Health Organization data.

Among the countries of the Baltic Sea is also the Russian Federation. However, due to non-comparable proportions and differences in law, standards, and statistical reporting, separate studies are proposed for the Northwestern Federal District. This district is of great importance for the development of the whole economy of Russia. Firstly, it is located at the junction with developed EU countries and has more chances to integrate into the world economy than regions of other districts. Secondly, the border regions have access to the Baltic Sea and occupy a prominent place in the maritime activities of the whole country. Thirdly, the only exclave territory of Russia - Kaliningrad region - is located in this district.

Studies conducted on the spread of the COVID-19 epidemic in the Northwestern Federal District of Russia clearly show that the dynamics of disease spread in NWFD regions differ significantly. The northern regions of the NWFD differ in disease detection. In the Arkhangelsk and Murmansk regions 54,586 and 45,371 diseases were detected respectively. In the Arkhangelsk oblast over 48 thousand people recovered during this period, and in the Murmansk oblast over 43 thousand people died 552 and 886 people respectively. High morbidity level was also registered in Komi Republic: over 38 thousand infected people, over 36 thousand people recovered and 730 died. By February 15 the situation was gradually stabilizing and the number of new infections in these regions was over 100 people each. The situation is somewhat different in regions bordering the European Union. These are the Kaliningrad, Novgorod and Pskov regions and the Republic of Karelia. In these regions the number of detected cases was in the range of 30 thousand people, more than 20 thousand people recovered. At the same time, the number of deaths was 232 in Kaliningrad Oblast, 155 in Pskov Oblast and 113 in Novgorod Oblast (table 4).

Table 4. Main characteristics of the epidemic spread in the Northwestern Federal District as of February 15, 2021

\begin{tabular}{|l|c|c|c|c|c|}
\hline \multicolumn{1}{|c|}{ Northwestern Federal District } & Retrieved & New & Active & Recovered & Dead \\
\hline Arkhangelsk region & 54,586 & 194 & 5,445 & 48,589 & 552 \\
\hline Nenets Autonomous Okrug & 1,075 & 1 & 24 & 1,007 & 4 \\
\hline Vologda region & 36,682 & 231 & 4,074 & 31,895 & 713 \\
\hline Kaliningrad region & 26,616 & 148 & 2,451 & 23,933 & 232 \\
\hline Republic of Karelia & 38,889 & 165 & 4,208 & 34,410 & 271 \\
\hline Komi Republic & 38,338 & 121 & 616 & 36,992 & 730 \\
\hline Leningrad region & 33,784 & 191 & 2,828 & 30,446 & 510 \\
\hline Murmansk region & 45,371 & 144 & 1,378 & 43,107 & 886 \\
\hline Novgorod region & 25,965 & 110 & 3,453 & 22,399 & 113 \\
\hline Pskov region & 30,806 & 104 & 10,824 & 19,827 & 155 \\
\hline St. Petersburg & 354,196 & 1,093 & 74,481 & 269,203 & 10,512 \\
\hline
\end{tabular}

Source: compiled from Stopcoronavirus data 


\section{ENTREPRENEURSHIP AND SUSTAINABILITY ISSUES}

ISSN 2345-0282 (online) http://jssidoi.org/jesi/ 2021 Volume 9 Number 2 (December) http://doi.org/10.9770/jesi.2021.9.2(15)

The high level of infection in the northern regions of the Northwestern Federal District can be explained by the fact that the population there is concentrated in several cities with a very high proportion of migrants and active interaction of the population with other cities and countries. Temporary workers come to the northern regions for construction projects (due to high wages), while locals always prefer to travel to southern regions and countries for holidays.

The city of St. Petersburg stands out sharply from other subjects in the Northwestern Federal District of Russia. This city has the official status of a separate subject of the Russian Federation and has a great influence on the neighboring regions of the district. In St. Petersburg, 354,196 people have been diagnosed with coronavirus. This figure can be safely compared to the population of all the separately taken large cities-regional centers of the NWFD. St. Petersburg has the largest agglomeration in the Northwestern Federal District of Russia. The mobility of the population and the potential for infection here is very high. If we consider that the tradition of internal Russian migrants confirms close ties with the place of origin, labor migrants contribute to the spread of coronavirus infection when returning home from St. Petersburg or on shift work (temporary work limited to a period of 2-3 weeks) to the North. Increased mobility of migrants as well as tourism has become one of the most important factors in the spread of infection throughout the county. The spread of coronavirus in cities-regional centers also confirms a definite trend in the spread of infection.

In contrast to the average indicators for the federal district, the variation in the given indicators is much greater in the regions (table 5). For example, by the level of variation by two times, and the ratio between the maximum and minimum levels also differs by more than two times. The highest average nominal wages are fixed in the northern regions: the Murmansk Oblast - 74,358 rubles; the Komi Republic - 61,270 rubles; the Arkhangelsk Oblast - 58,637 rubles and of course the city of Saint Petersburg. Here nominal wages have been above 64,000 rubles for a long time. In traditionally European regions: Novgorod, Pskov and Kaliningrad regions, nominal wages are keeping over 30 thousand rubles. the growth rate of nominal wages during the pandemic slowed down a little. However, in most regions of the Northwestern District annual growth rates of nominal wages were observed (from $11.4 \%$ - the Vologda region to $0.8 \%$ - the Novgorod region). By the way, Novgorod oblast was minus $1.9 \%$ in real wage growth.

Table 5. Indicators of wages, inflation and unemployment in the regions of the Northwestern Federal District in 2020

\begin{tabular}{|l|c|c|c|c|c|c|}
\hline $\begin{array}{c}\text { Northwestern Federal } \\
\text { District }\end{array}$ & $\begin{array}{c}\text { Average monthly } \\
\text { nominal wage, } \\
\text { May 2020, } \\
\text { rubles. }\end{array}$ & $\begin{array}{c}\text { CPI, growth in } \\
\text { January-June } \\
2020 \text { to } \\
\text { January-June } \\
2019, \%\end{array}$ & $\begin{array}{c}\text { Growth of real } \\
\text { wages, January- } \\
\text { May 2020 to } \\
\text { January-May } \\
2019, \% .\end{array}$ & $\begin{array}{c}\text { Unemploym } \\
\text { ent rate, Q2 } \\
2020, \%\end{array}$ & $\begin{array}{c}\text { Increase in } \\
\text { unemployment, 2020 to Q2 } \\
2019, \%\end{array}$ & $\begin{array}{c}\text { Socio-Economic } \\
\text { Stress Index, CPI + } \\
\text { increase in } \\
\text { unemployment }\end{array}$ \\
\hline $\begin{array}{l}\text { Northwestern Federal } \\
\text { District }\end{array}$ & 55,793 & 2.9 & 4.5 & 5.0 & 1.5 & 4.4 \\
\hline Arkhangelsk region & 58,637 & 3.6 & 3.8 & 7.8 & 1.5 & 5.1 \\
\hline Vologda region & 42,910 & 3.1 & 8.2 & 6.5 & 2.7 & 5.8 \\
\hline Kaliningrad region & 36,661 & 2.7 & 4.2 & 5.2 & 0.5 & 3.2 \\
\hline Republic of Karelia & 47,313 & 2.9 & 5.5 & 9.4 & 1.7 & 4.6 \\
\hline Komi Republic & 61,270 & 4.1 & 2.6 & 8.3 & 1.0 & 5.1 \\
\hline Leningrad region & 47,545 & 2.5 & 2.7 & 5.1 & 1.2 & 3.7 \\
\hline Murmansk region & 74,358 & 2.9 & 6.4 & 8.2 & 3.5 & 6.4 \\
\hline Novgorod region & 31,892 & 2.9 & -1.9 & 5.7 & 2.6 & 5.5 \\
\hline Pskov region & 32,473 & 2.2 & 5.8 & 6.8 & 1.7 & 3.9 \\
\hline St. Petersburg & 64,265 & 2.7 & 4.5 & 2.7 & 1.3 & 4.0 \\
\hline
\end{tabular}

Source: compiled from Federal State Statistics Service data 


\section{ENTREPRENEURSHIP AND SUSTAINABILITY ISSUES}

ISSN 2345-0282 (online) http://jssidoi.org/jesi/ 2021 Volume 9 Number 2 (December)

http://doi.org/10.9770/jesi.2021.9.2(15)

Studies on the level of unemployment show that the Northwestern District has lower indicators compared to other districts of the Russian Federation. In the regions of the NWFD the level of unemployment is traditionally high in the northern regions. For example, in the Republic of Karelia - 9.4\% (unemployment growth of 1.7\%); Murmansk and Arkhangelsk regions $-8.2 \%$ and $7.8 \%$ respectively (unemployment growth of 3.5\% and $1.5 \%$ ). The unemployment rate in the Komi Republic was higher than the national average - 8.3\%, while the unemployment rate increased by $1.0 \%$. The lowest level of unemployment was in Leningrad and Kaliningrad regions $-5.1 \%$ and $5.2 \%$ respectively (unemployment increased by $1.2 \%$ and $0.5 \%$ ). It should be noted that in the NWFD the greatest damage from the pandemic crisis was observed in the spheres of retail trade, services and services, as well as in transport. The analysis shows that in these areas the situation worsened to such an extent that it created a zone of socio-economic stress and risk.

\section{Discussion}

Nowadays it is becoming obvious that COVID-19 has struck the economic and political systems of many countries and regions (Humer 2020). Science is looking for indisputable methods and indicators to overcome these unexpected crisis phenomena. If we consider the situation in the NWFD of Russia, on can refer to the sample of key indicators that affect the development of pandemic processes when diagnosing these phenomena (table 6). In the table below the main indicators influencing the development of crisis phenomena in the course of coronavirus for each NWFD region were shown.

Table 6. Values of the main indicators influencing the development of crisis phenomena

\begin{tabular}{|l|c|c|c|c|c|c|}
\hline Northwestern Federal District & $\begin{array}{c}\text { Share of urban } \\
\text { residents in the } \\
\text { total population, } \\
\%\end{array}$ & $\begin{array}{c}\text { Demo- } \\
\text { geographical } \\
\text { potential of the } \\
\text { region, people } \\
\text { per 1 km }\end{array}$ & $\begin{array}{c}\text { Poverty rate, } \\
\%\end{array}$ & $\begin{array}{c}\text { Life } \\
\text { expectancy at } \\
\text { birth, years }\end{array}$ & $\begin{array}{c}\text { The number of } \\
\text { employed people } \\
\text { beds per } \\
\text { capita } \\
\text { entering the region } \\
\text { to work, } \% \text { of the } \\
\text { employed population } \\
\text { of the region }\end{array}$ \\
\hline Arkhangelsk region & 78.5 & 53.5 & 12.5 & 72 & 5.2 & 1.01 \\
\hline Nenets Autonomous Okrugt & 73.3 & 17.7 & 9.7 & 71.5 & 5.2 & 18.21 \\
\hline Vologda region & 72.6 & 197.8 & 13.6 & 71.3 & 4.2 & 0.72 \\
\hline Kaliningrad region & 77.7 & 45.4 & 13.7 & 72.6 & 4.4 & 0.45 \\
\hline Republic of Karelia & 80.7 & 100.5 & 15.6 & 70.7 & 4.4 & 0.63 \\
\hline Komi Republic & 78.2 & 47.1 & 14.9 & 71.1 & 4.3 & 4.33 \\
\hline Leningrad region & 64.3 & 3414.9 & 8.4 & 72.5 & 2.3 & 2.09 \\
\hline Murmansk region & 92.2 & 23.6 & 9.9 & 71.7 & 6,4 & 2.26 \\
\hline Novgorod region & 71.3 & 407.4 & 13.8 & 69.7 & 2.8 & 0.79 \\
\hline Pskov region & 71.7 & 190.7 & 17 & 70 & 3.3 & 0.38 \\
\hline St. Petersburg & 100 & 1247.3 & 6.6 & 75.5 & 4.3 & 2.34 \\
\hline
\end{tabular}

Source: compiled from Federal State Statistics Service data

The overall impact on the crisis phenomena developed in the regions of the district shows that the largest cities and the agglomerations formed around them experience the greatest risks. This is understandable, since agglomerations have a higher population density and a greater intensity of interaction, especially due to migrant workers in the northern regions of the district, including rotational* settlements with a single ventilation system.

\footnotetext{
* Rotational camps are a complex of residential, cultural, amenity, sanitary and household buildings and structures designed to ensure the life of rotational workers located at the closest distance to the objects of work.
} 
The current economic crisis has no analogues either in the world or in Russia, as for the first time it is caused by epidemiological, rather than economic or political factors. The ESG-rating (RAEX, 2021) conducted among the regions of the Northwestern Federal District shows that the highest social risks are in the Pskov and Vologda regions (70 and 48 respectively) and the greatest environmental risks are identified in the Komi Republic and the Nenets Autonomous District and Karelia Republic (82,81 and 80 respectively). In the conducted rating a great attention was paid to the quality of management. According to this rating, the Nenets Autonomous Okrug, Leningrad Oblast and Saint Petersburg perform best (table 7).

Table 7. ESG-rating of the regions of the Northwestern Federal District in 2020

\begin{tabular}{|c|c|c|c|c|c|}
\hline $\begin{array}{l}\text { Northwestern Federal District } \\
\text { (NWFD) }\end{array}$ & Environmental & Social & Governance & $\begin{array}{l}\text { Place in the ESG } \\
\text { ranking }\end{array}$ & $\begin{array}{l}\text { Place in the } \\
\text { NWFD }\end{array}$ \\
\hline Arkhangelsk region & 73 & 41 & 66 & 71 & 8 \\
\hline Nenets Autonomous Okrugt & 81 & 1 & 13 & 21 & 3 \\
\hline Vologda region & 13 & 48 & 41 & 29 & 5 \\
\hline Kaliningrad region & 67 & 22 & 47 & 54 & 7 \\
\hline Republic of Karelia & 80 & 40 & 42 & 76 & 9 \\
\hline Komi Republic & 82 & 42 & 48 & 78 & 10 \\
\hline Leningrad region & 18 & 9 & 17 & 8 & 1 \\
\hline Murmansk region & 78 & 14 & 20 & 53 & 6 \\
\hline Novgorod region & 8 & 45 & 19 & 11 & 2 \\
\hline Pskov region & 66 & 70 & 79 & 80 & 11 \\
\hline St. Petersburg & 70 & 6 & 18 & 23 & 4 \\
\hline
\end{tabular}

Source: compiled from RAEX data

Some publications draw attention to the expected growth of social risks. In the NWFD, the expected growth will be leveled in the regions sparsely populated, specializing in oil and gas production (Nenets Autonomous Okrug and the Komi Republic). Oil and gas rent in these regions are intended for the welfare, health and education of the population.

\section{Conclusion}

It should be noted that the pandemic in the Baltic Sea countries and the NWFD regions was a very difficult lesson for all institutions of power, science (especially medicine), as well as for structures and institutions involved in ensuring the existence of people.

COVID-19, which broke out unexpectedly, has brought about many problems that humanity has never faced before. The study presents the results of actions undertaken by nation states, showing mistakes and miscalculations. This is illustrated by the conclusions drawn as a result of the COVID-19 project. These conclusions should be considered in the future when similar challenges and crises emerge.

The literature review section shows that the scientific literature has responded quite actively to the course of the pandemic and that new proposals, methods and tools have arisen. A detailed analysis of the course of COVID-19 was carried out, as well as what negative phenomena were noted and what measures were taken to eliminate them, using the example of the Baltic Sea countries and border regions of the Northwestern Federal District of the Russian Federation.

The border regions of the Northwestern Federal District of Russia could not avoid mistakes either. These issues are discussed in the discussion section. In the northern regions, where there was a massive movement of labor force and population, the infection rates were much higher than in the entire Russian Federation. COVID-19 was 


\section{ENTREPRENEURSHIP AND SUSTAINABILITY ISSUES}

ISSN 2345-0282 (online) http://jssidoi.org/jesi/ 2021 Volume 9 Number 2 (December)

http://doi.org/10.9770/jesi.2021.9.2(15)

much more severe in underdeveloped regions, where there was a lack of basic resources and personnel in medical institutions, so the infection rates were high.

Thus, the proposed diagnosis in this study provides specific tools, methodology and forecasting for the outgoing from the coronavirus crisis, as well as the adoption of specific measures to assist affected businesses, business entities, the population and the definition of precautionary measures for the prevention and treatment of viral diseases. The materials of the study are of interest to scientists and practitioners who deal with the problems of crisis phenomena in regional and border systems, as well as challenges and emerging phenomena similar to the COVID-19 coronavirus pandemic.

\section{References}

Adams-Prassl, A., Boneva, T., Golin, M., \& Rauh, C. (2020). Inequality in the impact of the coronavirus shock: evidence from real time surveys, IZA. Retrieved April 21, 2020, from https://www.inet.econ.cam.ac.uk/working-paper-pdfs/wp2018.pdf

Baker, S.R., Bloom, N., Davis, S.J., \& Terry, S.J.. (2020). COVID-Induced Economic Uncertainty. National Bureau of Economic Research. Retrieved March 12, 2021, from https://www.nber.org/papers/w26983. https://dx.doi.org/10.3386/w26983

Balashov, A.P. (2004). Antikrizisnoe upravlenie. Novosibirsk, 167.

Beland, L.-P., Brodeur, A., \& Wright, T. (2020). The Short-Term Economic Consequences of Covid-19: Exposure to Disease, Remote Work and Government Response, Social Science Research Network. Retrieved April 16, 2021, from https://papers.ssrn.com/abstract=3584922

Belyaev, A.A. (2015). Antikrizisnoe upravlenie. Moskva: YUniti, 311.

Bilchak, M. (2011). On the assessment of cross-border regions' development potential, The Baltic Region, 2(8), 119-124. https://dx.doi.org/10.5922/2079-8555-2011-2-14

Biyakov, O.A. (2004). Teoriya ekonomicheskogo prokonstranstva: metodologicheskij i regional'nyj aspekty. Tomsk: Izdatelstvo Tomskogo universiteta.

Breznau, N. (2021). The welfare state and risk perceptions: The Novel Coronavirus Pandemic and public concern in 70 countries. European Societies, 23 (1), 33-46, https://doi.org/10.1080/14616696.2020.1793215

Coccia, M. (2020). Factors determining the diffusion of COVID-19 and suggested strategy to prevent future accelerated viral infectivity similar to COVID. Science of the Total Environment, 729. https://dx.doi.org/10.1016/j.scitotenv.2020.138474

Claeson, M. \& Hanson, S. (2021). COVID-19 and the Swedish enigma. The Lancet, 397 (10271), $259-261$. https://dx.doi.org/10.1016/S0140-6736(20)32750-1

Ehlert, A. (2020). The socio-economic determinants of COVID-19: A spatial analysis of German county level data. Retrieved April 16, 2021, from https://www.medrxiv.org/content/10.1101/2020.06.25.20140459v1. https://dx.doi.org/10.1101/2020.06.25.20140459

Federal State Statistics Service. Retrieved February 22, 2021, from https://eng.rosstat.gov.ru

Hauser, A., Counotte, M., Margossian, C., Konstantinoudis, G., Low, N., Althaus, C., \& Riou J. (2020). Estimation of SARS-CoV-2 mortality during the early stages of an epidemic: a modelling study in Hubei, China and Northern Italy. Retrieved February 2, 2021, form https://www.medrxiv.org/content/10.1101/2020.03.04.20031104v3 . https://dx.doi.org/10.1371/journal.pmed.1003189

Hennig, A. (2021). The spatial dimension of coronavirus crisis management and the role of subnational actors in the German-Polish border region. European Societies, 23(1). https://dx.doi.org/10.1080/14616696.2020.1846065 


\section{ENTREPRENEURSHIP AND SUSTAINABILITY ISSUES}

ISSN 2345-0282 (online) http://jssidoi.org/jesi/ 2021 Volume 9 Number 2 (December)

http://doi.org/10.9770/jesi.2021.9.2(15)

Hensvik, L., Le Barbanchon, T., \& Rathelot R. (2021). Job search during the COVID-19 crisis. Journal of Public Economics, 194. Retrieved March 1, 2021, from https://www.sciencedirect.com/science/article/pii/S0047272720302139. https://dx.doi.org/10.1016/j.jpubeco.2020.104349

Humer, A. (2020). The Corona pandemic is probing our societal basis: the functioning of Service of General Interest in cities and regions. Retrieved May 19, 2021, form https://ersa.org/forumcoronavirus/

Janssen, M., \& van der Voort, H. (2020) Agile and adaptive governance in crisis response: lessons from the COVID-19 pandemic. International Journal of Information Management, 55. https://dx.doi.org/10.1016/j.ijinfomgt.2020.102180

Jańczak, J. (2020). The German-Polish border, re-bordering and the pandemic: centers vs. peripheries? Working Paper Series B/ORDERS IN MOTION Nr. 8, Frankfurt (Oder), Vadrina, 17-19. January 22, 2021, from https://repozytorium.amu.edu.pl/bitstream/10593/25862/1/129.\%202020\%20G-P\%20border\%20under\%20Covid.pdf

Kucharski, A.J., Russell, T.W., Diamond, C., Liu, Y., Edmunds, J., Funk, S., \& Eggo, R.M. (2020). Early dynamics of transmission and control of COVID-19: A mathematical modelling study. Lancet Infect. Diseases, 20(5), 553-558. https://dx.doi.org/10.1016/S1473$\underline{3099(20) 30144-4}$

Klatt, M. (2020). What has happened to our cross-border regions? Corona, unfamiliarity and transnational borderland activism in the Danish-German borderregion. Borders in Perspective, 4, 43-47.

Knickel, M., Neuberger, S., Klerkx, L., Knickel, K., Brunori, G., \& Saatkamp, H. (2021). Strengthening the Role of Academic Institutions and Innovation Brokers in Agri-Food Innovation: Towards Hybridisation in Cross-Border Cooperation. Sustainability, 13(4899). https://dx.doi.org/10.3390/su13094899

Knight, F. (2017). Risk, uncertainty and profit. New edition, Wilmington: Vernon Art and Science Incorporated.

Korolev, I. (2020). Identification and Estimation of the SEIRD Epidemic Model for COVID-19. Retrieved February 8, 2021, form https://ssrn.com/abstract=3569367. https://dx.doi.org/10.2139/ssrn.3569367

Korotkov, M. (2020). Antikrizisnoe upravlenie. Moskva: Urajt, 406.

König, M., \& Winkler, A. (2021). COVID-19: Lockdowns, Fatality Rates and GDP Growth. Intereconomics, 56, 32-39. https://dx.doi.org/10.1007/s10272-021-0948-y

Larionov, I.K., Bragin, N.I., \& Gerasin, A.N. (2019). Antikrizisnoe upravlenie. Moskva: Dashkov i Kº 380.

Ludvigson, S.C., Ma, S., \& Ng, S. (2020). COVID-19 and the Macroeconomic Effects of Costly Disasters. National Bureau of Economic Research. Retrieved February 11, 2021, from https://www.nber.org/papers/w26987. https://dx.doi.org/10.3386/w26987

Marinov, M. (2020). Denmark and COVID-19, BSP Policy Briefing Series, 5. Retrieved February 11, 2021, https://www.researchgate.net/publication/346036552

Opiłowska, E. (2021). The Covid-19 crisis: the end of a borderless Europe? European Societies, 23(1). https://dx.doi.org/10.1080/14616696.2020.1833065

RAEX. Retrieved January, 29, 2021 from https://raex-a.ru/rankings/regions/ESG_raiting\#metodika

Shet, A., Ray, D., Malavige, N., Santosham, M., \& Bar-Zeev, N. (2020). Differential COVID-19-attributable mortality and BCG vaccine use in countries. Retrieved February 8, 2021, form https://www.medrxiv.org/content/10.1101/2020.04.01.20049478v1. https://doi.org/10.1101/2020.04.01.20049478

Sohn, C. (2014). Modelling Cross-Border Integration: The Role of Borders as a Resource. Geopolitics, 19(3), 587-608.

Stopcoronavirus. Retrieved February 15, 2021, from https://стопкоронавирус.rf/information/

Van Dam, Y.K. \& Webbink, J.F. (2020). Reflecting on reflections on CoViD-19. CEREM, 4(2), 7-19. https://dx.doi.org/10.29015/cerem.876 


\section{ENTREPRENEURSHIP AND SUSTAINABILITY ISSUES}

ISSN 2345-0282 (online) http://jssidoi.org/jesi/

2021 Volume 9 Number 2 (December)

http://doi.org/10.9770/jesi.2021.9.2(15)

Will, M. (2020). The CoViD-19 Pandemic and the End of Corporate Risk Management as we know it. CEREM, 4(3), 89-115. https://dx.doi.org/10.29015/cerem. 888

World Health Organization. Retrieved March 24, 2021, from https://covid19.who.int/table

Wu, J.T., Leung, K., \& Leung, G.M. (2020). Nowcasting and forecasting the potential domestic and international spread of the 2019-nCoV outbreak originating in Wuhan, China: a modelling study. Lancet Infect. Diseases, 395, 689-697. https://dx.doi.org/10.1016/S0140$\underline{6736(20) 30260-9}$

Zemtsov, S., Barinova, V., \& Semenova, R. (2019). The Risks of Digitalization and the Adaptation of Regional Labor Markets in Russia. Foresight and STI Governance, 13 (2), 84-96. https://dx.doi.org/10.17323/2500-2597.2019.2.84.96

Zgonnik, L.V. (2015). Antikrizisnoe upravlenie. Moskva: Dashkov i Kº 208.

Zizka, L. (2020). Coronavirus crisis communication: a wicked problem. Retrieved April 6, 2021, form https://hospitalityinsights.ehl.edu/covid19-crisis-communication

Michal BILCZAK is the Adjunct of the University of Warmia and Mazury in Olsztyn, The Faculty of Economic Sciences. Research interests: cross-border cooperation, regional economics

ORCID ID: orcid.org/0000-0001-7008-5132

Make your research more visible, join the Twitter account of ENTREPRENEURSHIP AND SUSTAINABILITY ISSUES: @Entrepr69728810

Copyright (C) 2021 by author(s) and VsI Entrepreneurship and Sustainability Center

This work is licensed under the Creative Commons Attribution International License (CC BY).

http://creativecommons.org/licenses/by/4.0/

(c) (i) Open Access 